\title{
A Review of the Phytochemistry, Traditional Uses and Antibacterial Potential of Psidium guajava
}

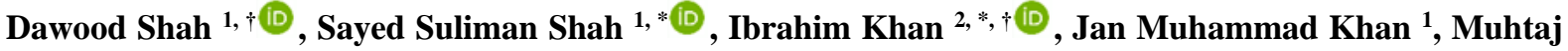

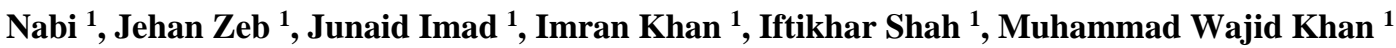 \\ 1 Department of Chemistry, Government Degree College No. 2 Mardan, Abdul Wali Khan University Mardan, Khyber \\ Pakhtunkhwa, Pakistan \\ 2 Department of Biotechnology, School of Life Sciences and Technology, University of Electronic Science and Technology \\ of China \\ * Correspondence: suliman191@yahoo.com (S.S.S.); ibrahimkhan.qau@yahoo.com (I.K.); \\ $\dagger$ First and third author contributed equally to this work;
}

Scopus Author ID 57220990378

Received: 19.10.2020; Revised: 30.12.2020; Accepted: 10.01.2021; Published: 19.01.2021

\begin{abstract}
Psidium guajava is a tropical evergreen tree. It belongs to the family Myrtaceae that consists of about 133 genera and approximately 3800 species worldwide. This plant is mainly found in South Africa, North Africa, South America, and Southeast Asia. Psidium guajava is mainly a nutritional plant, but it also shows various biological activities. An array of bioactive constituents, viz; glycosides, terpenoids, tannins, alkaloids, steroids, saponins, amino acids, anthraquinones, proteins, flavonoids, and phenols, etc. have been isolated from Psidium guajava. These phytochemicals are well known for their biological activities, including antibacterial, antioxidant, antifungal, etc. The present work has been performed to gather data about the traditional uses, important phytochemicals, and antibacterial efficiency of Psidium guajava. Many pharmacological studies have demonstrated its antibacterial potential against various important drug resistive pathogens. We invite researchers' attention to carry out detailed antibacterial studies on this valuable plant species to provide reliable knowledge to the patients and discover more novel compounds for the development of new drugs with fewer side effects compared to conventional medicines.
\end{abstract}

Keywords: Psidium guajava; Myrtaceae; antibacterial; traditional medicines; phytochemicals; drugresistive pathogens; medicinal plants.

(C) 2020 by the authors. This article is an open-access article distributed under the terms and conditions of the Creative Commons Attribution (CC BY) license (https://creativecommons.org/licenses/by/4.0/).

\section{Introduction}

Psidium guajava (commonly known as guava) is a small tropical evergreen tree. It belongs to the phylum Magnoliophyta, class Magnoliopsida, and family Myrtaceae consisting of about 133 genera and approximately 3800 species worldwide [1]. Psidium guajava is best known for its fruits and grows up to 35 feet in height. This plant has wide-spreading branches, on which the leaves are oppositely arranged $[2,3]$. The flowers of Psidium guajava are white that are usually borne singly in the upper leaf axils, having four or five incurved white petals and four or five green sepals and yellow anthers [4]. Psidium guajava is mainly found in South America, South Africa, West Africa, South East Asia, South India, Sri Lanka, Hawaii, Bangladesh, Pakistan, and Egypt, etc. [5]. This plant has now been grown by many other countries having a tropical and subtropical climate. Psidium guajava is used as a nutritional food worldwide. However, different extracts of Psidium guajava show several biological 
activities, including antibacterial, antioxidant, antifungal, antimalarial, antitussive effects, hepatoprotective, antigenotoxic effects, antimutagenic effects, anti-cancer effects, antihyperglycemic, anti-inflammatory, wound healing, cardiovascular, hypotensive effects and antiallergic effects, etc. [6]. Traditionally, Psidium guajava has been used to treat diabetes, diarrhea, gastroenteritis, caries, stomach-ache, hypertension, toothache, vomiting, ulcers, inflamed gums, coughs, and malaria, etc. [7]. Psidium guajava contains various phytochemicals viz; Proteins, minerals, polysaccharides, alkaloids, vitamins, steroids, essential oils, glycosides, minerals, flavonoids, enzymes, tannins, sesquiterpenoid alcohols, saponins, and triterpenoid acids, glycoalkaloids, carotenoids and alkenyl phenols etc. [6, 8].

Presently, antibiotic-resistant-pathogens have become a global issue due to the overdosage of drugs, which leads to the decreased efficiency of conventional medicines [9]. The average duration since using an antibiotic to become resistant is approximately 6.6 years [10]. Due to an unhygienic environment, food intake, and lack of awareness of a healthy lifestyle, people from developing countries are exposed to such diseases caused by drugresistant pathogens. This problem is very staid and shows that new antibiotics must be developed as the existing antibiotics will be no longer effective forever. Therefore, proper strategies should be adopted to develop and synthesis new antibacterial drugs that can be used to combat drug-resistive pathogens. A vast majority of plants have bioactive constituents that can overcome the pathogens' resistance [11]. Several studies report that Psidium guajava has sufficient antibacterial activities and can be used to combat the pathogens' problem of resistance. Due to the utmost attention towards the development and synthesis of antibacterial drugs from plants, we present a review of the existing literature about the phytochemistry, traditional uses, and antibacterial potential of Psidium guajava. Therefore, the present study is designed to review different in vivo and in vitro pharmacological studies and gather the fragmented literature about the phytochemistry, traditional uses, and antibacterial potential of Psidium guajava. Moreover, this review would help provide easy access to the antibacterial work performed on Psidium guajava and to develop new drugs against the drug-resistant bacterial species.

\section{Psidium guajava in Traditional Medicines}

Traditional techniques have been used for thousands of years for the treatment of several different diseases. Almost 2500 plant species have been used for medicinal purposes [12]. Psidium guajava is one of the most useful medicinal plants used in traditional medicines to treat various diseases viz; diabetes, diarrhea, gastroenteritis, caries, stomach-ache, hypertension, toothache, vomiting, ulcers, inflamed gums, coughs, and malaria, etc. (Figure 1) $[13,14]$. It has been reported that fruit and leaves of Psidium guajava have been used to treat cancer prevention [15]. Psidium guajava's leaves, barks, roots, and immature fruits have been used to treat dysentery, gastroenteritis, and diarrhea [16]. Leaves of Psidium guajava have been reported to be used for rheumatic pain, wounds, ulcers, and toothache. Also, leaves of Psidium guajava reduce glucose levels in the blood $[17,18]$.

\section{Phytochemistry of Psidium guajava}

An array of bioactive constituents viz; glycoside, terpenoid, tannin, alkaloid, steroid, saponin, amino acid, anthraquinones, protein, flavonoids, and phenols, etc. have been isolated from Psidium guajava (Scheme 1; Scheme 2). These phytochemicals are best known for their 
antibacterial, antioxidant, antiviral, antifungal, and anti-inflammatory properties. Some of the important classes of compounds and their IUPAC names and general formula isolated from Psidium guajava are given in Table 1.

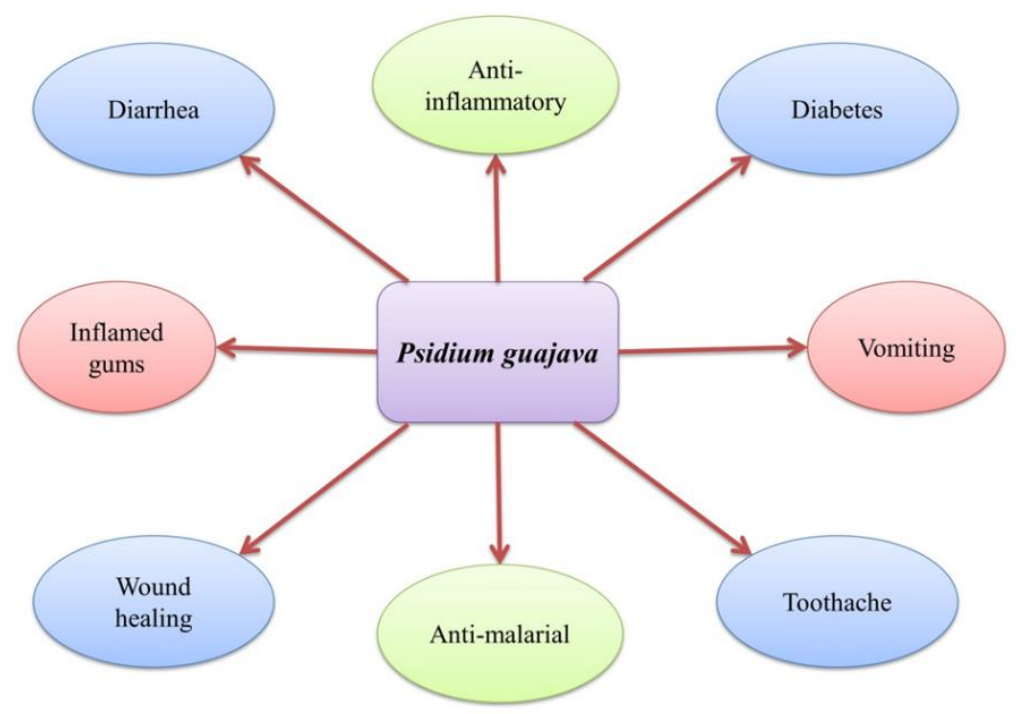

Figure 1. Some important traditional uses of Psidium guajava.<smiles>COc1cc(/C=C/C(=O)O)ccc1O</smiles>

1<smiles>C=C(/C=C/c1ccc(O)c(O)c1)O[C@H]1[C@H](O)[C@@H](O)[C@H](O)[C@H](O)[C@H]1O</smiles><smiles></smiles>

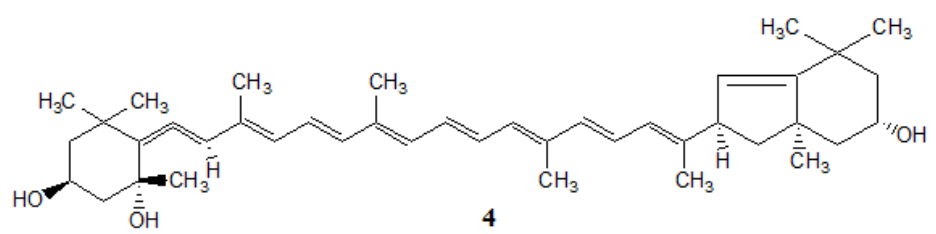<smiles>CC(/C=C/C=C/C(C)/C=C/C=C(\C)C1C=C2C(C)(C)CC(O)CC2(C)O1)=C\C=C\C(C)=C\C=C\C1C(C)CCCC1(C)C</smiles><smiles>CC(C)=CCC/C(C)=C/C=C/C(C)=C/C=C/C(C)=C/C=C/C=C(C)/C=C/C=C(C)/C=C/C1=C(C)C[C@@H](O)CC1(C)C</smiles>

6<smiles>CC1=CC(O)CC(C)(C)C1/C=C/C(C)=C/C=C/C(C)=C/C=C/C=C(C)/C=C/C=C(C)/C=C/C1=C(C)C[C@@H](O)[C@H](C)C1</smiles>

Scheme 1. Chemical structures of compounds 1-7 isolated from Psidium guajava. 
<smiles>CC(C)=CCC/C(C)=C/C=C/C(C)=C/C=C/C(C)=C/C=C/C=C(C)/C=C/C=C(C)/C=C/C=C(\C)CCC=C(C)C</smiles><smiles>O=c1oc2c(O)c(OC3OC(COC4OC(CCO)C(O)C(O)C4O)C(O)C(O)C3O)cc3c(=O)oc4c(O)c(O)cc1c4c23</smiles>

9<smiles>O=c1c(O)c(-c2ccc(O)c(O)c2)oc2cc(O)cc(O)c12</smiles><smiles>O=C(O)[C@H]1O[C@@H](Oc2ccc(-c3oc4cc(O)cc(O)c4c(=O)c3O)cc2O)[C@H](O)[C@@H](O)[C@H]1O</smiles>

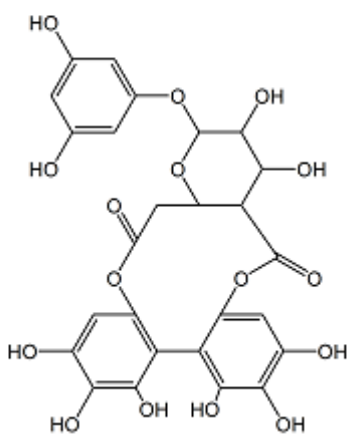

10<smiles>COC1=CC(O)=CC2OC(c3ccc(O)c(O)c3)=C(C[C@H]3O[C@@H](C)[C@H](O)[C@H]3O)C(=O)C12</smiles>

12

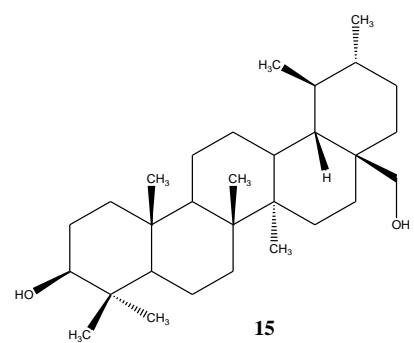

Scheme 2. Chemical structures of compounds 8-15 isolated from Psidium guajava.

Table 1. Some essential phytochemicals isolated from Psidium guajava.

\begin{tabular}{|c|c|c|c|c|}
\hline S. No. & Phytochemicals & IUPAC Name & $\begin{array}{l}\text { General } \\
\text { formula }\end{array}$ & Ref. \\
\hline \multicolumn{5}{|l|}{ Fatty acids } \\
\hline 1 & Ferulic acid & (E)-3-(4-hydroxy-3-methoxyphenyl)prop-2-enoic acid & $\mathrm{C}_{10} \mathrm{H}_{10} \mathrm{O}_{4}$ & [19] \\
\hline 2 & Chlorogenic acid & $\begin{array}{l}1 S, 3 R, 4 R, 5 R)-3-[(E)-3-(3,4 \text {-dihydroxyphenyl)prop-2-enoyl]oxy-1,4,5- } \\
\text { trihydroxycyclohexane-1-carboxylic acid }\end{array}$ & $\mathrm{C}_{16} \mathrm{H}_{18} \mathrm{O}_{9}$ & {$[20]$} \\
\hline 3 & Ellagic acid & $\begin{array}{l}\text { 6,7,13,14-tetrahydroxy-2,9-dioxatetracyclo }\left[6.6 .2 \cdot 0^{4,16} \cdot 0^{11,15}\right] \text { hexadeca- } \\
1(15), 4,6,8(16), 11,13 \text {-hexaene-3,10-dione }\end{array}$ & $\mathrm{C}_{14} \mathrm{H}_{6} \mathrm{O}_{8}$ & {$[21]$} \\
\hline \multicolumn{5}{|c|}{ (2) } \\
\hline 4 & Neochrome & $\begin{array}{l}\text { 2-[(2Z,4E,6E,8E,10E,12E,14Z)-15-(6-hydroxy-4,4,7a-trimethyl- } \\
\text { 2,5,6,7-tetrahydro-1-benzofuran-2-yl)-6,11-dimethylhexadeca- }\end{array}$ & $\mathrm{C}_{40} \mathrm{H}_{56} \mathrm{O}_{4}$ & {$[22]$} \\
\hline
\end{tabular}




\begin{tabular}{|c|c|c|c|c|}
\hline S. No. & Phytochemicals & IUPAC Name & $\begin{array}{l}\text { General } \\
\text { formula }\end{array}$ & Ref. \\
\hline & & $\begin{array}{l}2,4,6,8,10,12,14-h e p t a e n-2-y l]-4,4,7 a \text {-trimethyl-2,5,6,7-tetrahydro-1- } \\
\text { benzofuran-6-ol }\end{array}$ & & \\
\hline 5 & Criptoflavin & $\begin{array}{l}\text { 4-[(1E,3E,5E,7E,9E,11E,13E,15Z)-16-(4,4,7a-trimethyl-2,5,6,7- } \\
\text { tetrahydro-1-benzofuran-2-yl)-3,7,12-trimethylheptadeca- } \\
1,3,5,7,9,11,13,15 \text {-octaenyl]-3,5,5-trimethylcyclohex-3-en-1-ol }\end{array}$ & $\mathrm{C}_{40} \mathrm{H}_{56} \mathrm{O}_{2}$ & {$[22]$} \\
\hline 6 & Rubixanthin & $\begin{array}{l}(1 R)-4-[(1 E, 3 E, 5 E, 7 E, 9 E, 11 E, 13 E, 15 E, 17 E, 19 E)-3,7,12,16,20,24- \\
\text { hexamethylpentacosa-1,3,5,7,9,11,13,15,17,19,23-undecaenyl]-3,5,5- } \\
\text { trimethylcyclohex-3-en-1-ol }\end{array}$ & $\mathrm{C}_{40} \mathrm{H}_{56} \mathrm{O}$ & [22] \\
\hline 7 & Lutein & $\begin{array}{l}(1 R)-4-[(1 E, 3 E, 5 E, 7 E, 9 E, 11 E, 13 E, 15 E, 17 E)-18 \text {-[(1R,4R)-4-hydroxy- } \\
\text { 2,6,6-trimethylcyclohex-2-en-1-yl]-3,7,12,16-tetramethyloctadeca- } \\
1,3,5,7,9,11,13,15,17 \text {-nonaenyl]-3,5,5-trimethylcyclohex-3-en-1-ol }\end{array}$ & $\mathrm{C}_{40} \mathrm{H}_{56} \mathrm{O}_{2}$ & [22] \\
\hline 8 & Lycopene & $\begin{array}{l}(6 E, 8 E, 10 E, 12 E, 14 E, 16 E, 18 E, 20 E, 22 E, 24 E, 26 E)- \\
2,6,10,14,19,23,27,31 \text {-octamethyldotriaconta- } \\
2,6,8,10,12,14,16,18,20,22,24,26,30 \text {-tridecaene }\end{array}$ & $\mathrm{C}_{40} \mathrm{H}_{56}$ & {$[22]$} \\
\hline \multicolumn{5}{|c|}{ 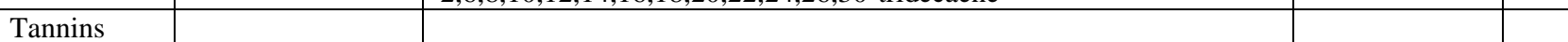 } \\
\hline 9 & Amritoside & $\begin{array}{l}\text { 6,7,14-trihydroxy-13-[3,4,5-trihydroxy-6-[[3,4,5-trihydroxy-6- } \\
\text { (hydroxymethyl)oxan-2-yl]oxymethyl]oxan-2-yl]oxy-2,9- } \\
\left.\text { dioxatetracyclo[6.6.2. } 0^{4,16} \cdot 0^{11,15}\right] \text { hexadeca-1(15),4,6,8(16),11,13- } \\
\text { hexaene-3,10-dione }\end{array}$ & $\mathrm{C}_{26} \mathrm{H}_{26} \mathrm{O}_{18}$ & [23] \\
\hline 10 & Guavin-B & $\begin{array}{l}\text { 13-(4-benzoyl-3,5-dihydroxyphenoxy)-3,4,5,11,12,21,22,23- } \\
\left.\text { octahydroxy-9,14,17-trioxatetracyclo[17.4.0. } 0^{2,7} \cdot 0^{10,15}\right] \text { tricosa- } \\
\text { 1(23),2,4,6,19,21-hexaene- } 8,18 \text {-dione }\end{array}$ & $\mathrm{C}_{33} \mathrm{H}_{26} \mathrm{O}_{17}$ & {$[24]$} \\
\hline \multicolumn{5}{|c|}{ (- } \\
\hline 11 & Quercetin & 2-(3,4-dihydroxyphenyl)-3,5,7-trihydroxychromen-4-one & $\mathrm{C}_{15} \mathrm{H}_{10} \mathrm{O}_{7}$ & [25] \\
\hline 12 & $\begin{array}{l}\text { Quercetin-3-O- } \\
\text { arabinoside }\end{array}$ & $\begin{array}{l}\text { 3-[(2R,3R,4R,5S)-3,4-dihydroxy-5-(hydroxymethyl)oxolan-2-yl]oxy- } \\
\text { 2-(3,4-dihydroxyphenyl)-5,7-dihydroxychromen-4-one }\end{array}$ & $\mathrm{C}_{5} \mathrm{H}_{10} \mathrm{O}_{5}$ & [26] \\
\hline 13 & $\begin{array}{l}\text { Quercetine 4- } \\
\text { glucuronicde }\end{array}$ & $\begin{array}{l}(2 S, 3 S, 4 S, 5 R, 6 S)-3,4,5 \text {-trihydroxy-6-[2-hydroxy-4-(3,5,7-trihydroxy- } \\
\text { 4-oxochromen-2-yl)phenoxy]oxane-2-carboxylic acid }\end{array}$ & $\mathrm{C}_{21} \mathrm{H}_{18} \mathrm{O}_{13}$ & [26] \\
\hline \multicolumn{5}{|l|}{ Triterpenoid } \\
\hline 14 & Arjunolic acid & 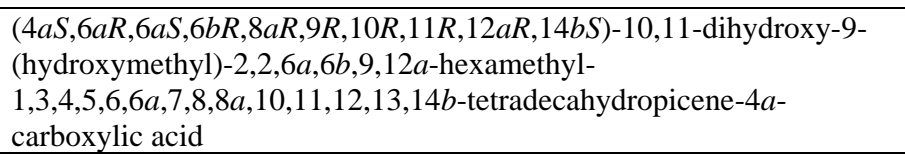 & $\mathrm{C}_{30} \mathrm{H}_{48} \mathrm{O}_{5}$ & {$[6]$} \\
\hline 15 & Uvaol & $\begin{array}{l}3 S, 4 a R, 6 a R, 6 b S, 8 a S, 11 R, 12 S, 12 a S, 14 a R, 14 b R) \text {-8a-(hydroxymethyl)- } \\
4,4,6 a, 6 b, 11,12,14 b \text {-heptamethyl- } \\
2,3,4 a, 5,6,7,8,9,10,11,12,12 a, 14,14 a \text {-tetradecahydro-1H-picen-3-ol }\end{array}$ & $\mathrm{C} 30 \mathrm{H} 50 \mathrm{O} 2$ & [27] \\
\hline
\end{tabular}

\section{Psidium guajava as an Antibacterial Agent}

Presently, resistive drug pathogens have been a major global threat to the health care system. Due to an unhygienic environment, food intake, and lack of awareness of a healthy lifestyle, people from developing countries are exposed to such diseases caused by drugresistant pathogens. A vast majority of plants have bioactive constituents that can overcome the pathogens' resistance [9]. Several studies report that Psidium guajava has sufficient antibacterial activities and can be used to combat the problem of resistance offered by the pathogens (Table 2). The antibacterial potential of n-butanol, acetone, chloroform, and ethanol extracts of Psidium guajava have been evaluated against selected species of bacteria, including Pseudomonas aeruginosa, Staphylococcus aureus, and Candida albicans. The study revealed that acetone extract showed maximum antibacterial activity against $P$. aeruginosa (inhibition zone $13.5 \pm 2.12 \mathrm{~mm})$. In contrast, chloroform extract showed maximum inhibition $(10.2 \pm$ $1.13 \mathrm{~mm}$ ) against $C$. albicans [28]. Another study revealed that the methanolic extract from the leaves of Psidium guajava shows remarkable inhibition against some selected Gram-positive and Gram-negative bacteria. The study revealed that the methanolic extracts showed maximum inhibition to Gram-positive bacteria, including Staphylococcus aureus and Bacillus cereus. However, the extracts were inactive against Gram-negative bacteria, including Salmonella typhimurium and Escherichia coli [29]. The antibacterial activities of hydroalcoholic and aqueous extracts of the leaves of Psidium guajava have been evaluated against two bacterial 
samples, including Escherichia coli and Bacillus cereus. The study results revealed that the hydroalcoholic extract of the plant was active against the bacterial samples, while the aqueous extract did not show any inhibition [30]. The ethanolic and chloroform extracts of two varieties of Psidium guajava fruits were evaluated for their antibacterial activity against selected bacterial strains, including Staphylococcus aureus and Escherichia coli. The results revealed that chloroform extract had no inhibitory effect against the selected strains of microorganisms [31]. Another study revealed that the ethanolic extract of Psidium guajava (in the form of a gel) obtained from the maceration with $70 \%$ ethanol has a profound inhibition against the Staphylococcus aureus. It was observed that increasing ethanolic extract of Psidium guajava increases the inhibition increases [32]. In vitro antibacterial potential of the ethanolic extract of the leaves of Psidium guajava has been determined against the antibiotic-resistant Staphylococcus aureus and Escherichia coli obtained from the urine of urinary tract infection (UTI) patient. These bacterial strains were also tested for their resistance to the antibiotic. The antibiotics used were Gentamicin (GEN), Nitrofurantoin (NIT), Ciprofloxacin (CIP), Cotrimoxazole (COT), Nalidixic acid (NA), and Ampicillin (AMP). It was observed that Ciprofloxacin (CIP) showed maximum inhibition (15 mm against Escherichia coli and $8 \mathrm{~mm}$ against Staphylococcus aureus) than the ethanolic extract of Psidium guajava leaves $(10 \mathrm{~mm}$ against Escherichia coli and $7 \mathrm{~mm}$ against Staphylococcus aureus) [33]. The antibacterial potential of the ethyl acetate extract of the Endophytic fungi viz; Aspergillus niger Van Tieghem, Aspergillus flavus, Aspergillus fumigatus Fres, and Aspergillus isolated from the surface of leaves of Psidium guajava has been determined by Kirby Bauer method against selected bacterial strains including Escherichia coli and Salmonella tiphi. It was concluded from this study that these Endophytic fungi have a strong potential to inhibit bacteria, and they can be used to develop new antibiotic drugs [34]. Another study also reported the antibacterial potential of ethanolic extracts of Psidium guajava against four clinically important bacterial strains, including Staphylococcus aureus, Escherichia col, Salmonella typhi, and Pseudomonas aeruginosa at two different temperatures and $\mathrm{PH}$. It was concluded from the study that at $\mathrm{PH}$ 6.0 and temperature $35^{\circ} \mathrm{C}$, the extracts show maximum inhibition $(S$. aureus $17-30 \mathrm{~mm}$, E. coli (18-26 mm), and S. typhi $(9-12 \mathrm{~mm})$. However, with an increase in temperature and $\mathrm{PH}$ the inhibition decreased [35]. Emmanuel et al. also reported the antibacterial activities of the essential oil and ethanol extracts of Psidium guajava against Escherichia coli, Staphylococcus aureus, Staphylococcus epidemidis, Proteus vulgari, Salmonella typhi, and Methicillinresistant Staphylococcus aureus. The results revealed that Staphylococcus epidemidis was maximum inhibited $(23 \mathrm{~mm})$ by the ethanolic extracts, while Staphylococcus aureus was most inhibited $(9 \mathrm{~mm})$ by the essential oil extracts [36]. The antibacterial efficiency of the ethanolic and aqueous extracts of the leaf of Psidium guajava against selected bacteria, namely Escherichia coli, Bacillus subtilis, Staphylococcus aureus, Shigellaflexnari, Proteus vulgaris, and Micrococcus luteus. The ethanolic extract showed maximum inhibition (up to $30 \mathrm{~mm}$ ) compared to the aqueous extract [37].

Table 2. Antibacterial activities of Psidium guajava.

\begin{tabular}{l|l|l} 
Extract & Susceptible bacteria & Ref. \\
\hline $\begin{array}{l}\text { n-butanol, acetone, chloroform, and ethanol } \\
\text { extracts }\end{array}$ & $\begin{array}{l}\text { Pseudomonas aeruginosa, Staphylococcus aureus, and Candida } \\
\text { albicans }\end{array}$ & {$[28]$} \\
\hline Methanolic extract & $\begin{array}{l}\text { Staphylococcus aureus, Escherichia coli, Bacillus cereus, } \\
\text { and Salmonella typhimurium }\end{array}$ & {$[29]$} \\
\hline Hydroalcoholic and aqueous extracts & Escherichia coli and Bacillus cereus & {$[30]$} \\
\hline Ethanolic and chloroform extracts & Staphlococcus aureus and Escherichia coli & {$[31]$} \\
\hline $\begin{array}{l}\text { Ethanolic extract } \\
\text { https://nanobioletters.com/ }\end{array}$ & Staphylococcus aureus & {$[32]$} \\
\hline
\end{tabular}




\begin{tabular}{l|l|l} 
Extract & Susceptible bacteria & Ref. \\
\hline Ethanolic extract & Escherichia coli and Staphylococcus aureus & {$[33]$} \\
\hline Ethyl acetate extract & Escherichia coli and Salmonella tiphi & {$[34]$} \\
\hline Ethanolic extract & $\begin{array}{l}\text { Staphylococcus aureus, Pseudomonas aeruginosa Salmonella typhi, } \\
\text { and Escherichia coli }\end{array}$ & {$[35]$} \\
\hline Essential oil and ethanol extracts & $\begin{array}{l}\text { Escherichia coli, Staphylococcus aureus, Staphylococcus epidemidis, } \\
\text { Proteus vulgari, Salmonella typhi, and Methicillin-resistant } \\
\text { Staphylococcus aureus }\end{array}$ & {$[36]$} \\
\hline Ethanolic and aqueous extracts & $\begin{array}{l}\text { Escherichia coli, Bacillus subtilis, Staphylococcus aureus, } \\
\text { Shigellaflexnari, Proteus vulgaris and Micrococcus luteus }\end{array}$ & {$[37]$}
\end{tabular}

It has been suggested that the antibacterial potential of the root extracts of Psidium guajava is much higher than the leaves extracts [38]. This might be due to the greater quantity of bioactive constituents present in the roots of Psidium guajava.

\section{Conclusion}

Different pharmacological and phytochemical studies about Psidium guajava indicate that this plant has significant antibacterial potential as it is rich in bioactive constituents. The present study gathers the data from various recent research and review articles about the antibacterial efficiency of Psidium guajva. It is concluded from the current work that Psidium guajava is one of the most efficient antibacterial agents and can be used for the synthesis of various antibacterial drugs against most of the drug-resistive pathogens. Different findings of researchers cited in this paper confirmed the promising antibacterial potential of Psidium guajava. Moreover, Psidium guajava can be used as an alternative antibacterial agent to treat various bacterial infections. Despite many important bioactive phytochemicals present in Psidium guajava, some harmful constituents also exist in this plant. Therefore, it is important to reveal the detailed mechanism behind these phytochemical and antibacterial activities.

\section{Funding}

This research received no external funding.

\section{Acknowledgments}

The authors are thankful to the Head of the Chemistry Department, Government Degree College No. 2 Mardan, for his cooperation, timely suggestions, and encouragement.

\section{Conflicts of Interest}

The authors declare no conflict of interest.

\section{References}

1. Naseer, S.; Hussain, S.; Naeem, N.; Pervaiz, M.; Rahman, M. The phytochemistry and medicinal value of Psidium guajava (guava). Clinical Phytoscience 2018, 4, http://doi.org/10.1186/s40816-018-0093-8.

2. Sahu, D.M.; Pandey, S.; Bharti, S. Topical Fruit Apple of the Poor's People (Psidium guajava L.). International Journal of Life-Sciences Scientific Research 2016, 2, 548-551, http://doi.org/10.21276/ijlssr.2016.2.5.6.

3. Uzzaman, S.; Akanda, K. M.; Mehjabin, S.G.; Masud Parvez, M. A short review on a Nutritional Fruit: Guava. Open Access: Toxicology \& Research 2018, 1, 1-8.

4. Omayio, D.G.; Abong, G.O.; Okoth, M.W.; Gachuiri, C.K.; Mwang'ombe, A.W. Current Status of Guava (Psidium Guajava L) Production, Utilization, Processing and Preservation in Kenya: A Review. Current Agriculture Research Journal 2019, 7, 318-331, http://doi.org/10.12944/carj.7.3.07. 
5. Saleh, B.; Al-Mariri, A. Antibacterial Activity Evaluation of Psidium guajava L . ( Myrtaceae ) Crude Extracts Against Selected Bacterial Pathogens. Pakistan Journal of Scientific and Industrial Research Series B: Biological Sciences 2020, 2, 119-126.

6. Gutiérrez, R.M.P.; Mitchell, S.; Solis, R.V. Psidium guajava: A review of its traditional uses, phytochemistry and pharmacology. Journal of Ethnopharmacology 2008, 117, 1-27, http://doi.org/10.1016/j.jep.2008.01.025.

7. Díaz-de-Cerio, E.; Verardo, V.; Gómez-Caravaca, A.M.; Fernández-Gutiérrez, A.; Segura-Carretero, A. Health effects of Psidium guajava L. Leaves: An overview of the last decade. International Journal of Molecular Sciences 2017, 18, http://doi.org/10.3390/ijms18040897.

8. Kaneria, M.; Chanda, S. Phytochemical and pharmacognostic evaluation of leaves of Psidium guajava L. (Myrtaceae). Pharmacognosy Journal 2011, 3, 41-45, http://doi.org/10.5530/pj.2011.23.6.

9. Shah, S.S.; Shah, D.; Khan, I.; Ilyas, M.; Jan, S.A. Bergenia ciliata as antibacterial agent. GSC Biological and Pharmaceutical Sciences 2020, 12, 37-45, https://doi.org/10.30574/gscbps.2020.12.2.0206.

10. Soliman, F.M.; Fathy, M.M.; Salama, M.M.; Saber, F.R. Comparative study of the volatile oil content and antimicrobial activity of Psidium guajava L. and Psidium cattleianum Sabine leaves. Bulletin of Faculty of Pharmacy, Cairo University 2016, 54, 219-225, http://doi.org/10.1016/j.bfopcu.2016.06.003.

11. Khan, I.; Najeebullah, S.; Ali, M.; Shinwari, Z.K. Phytopharmacological and ethnomedicinal uses of the Genus Berberis ( Berberidaceae ): A review. Tropical Journal of Pharmaceutical Research 2016, 15, 20472057, http://doi.org/10.4314/tjpr.v15i9.33.

12. Khan, I.; Jan, S.A.; Shinwari, Z.K.; Ali, M.; Khan, Y.; Kumar, T. Ethnobotany and Medicinal Uses of Folklore Medicinal Plants Belonging to Family Acanthaceae: An Updated Review. MOJ Biology and Medicine 2017, 1, http://doi.org/10.15406/mojbm.2017.01.00009.

13. Bulut, G.; Haznedaroğlu, M. Z.; Doğan, A.; Koyu, H.; Tuzlacı, E. An ethnobotanical study of medicinal plants in Acipayam (Denizli-Turkey). Journal of Herbal Medicine 2017, 10, 64-81, http://doi.org/10.1016/j.hermed.2017.08.001.

14. Kumari, R.; Kumar, A.; Kumar, B. Ethnobotanical Investigation of Medicinal Plants used by Rural Communities of District Chatra, Jharkhand, India. IOSR Journal of Biotechnology and Biochemistry 2019, 5, 34-49.

15. Correa, M.G.; Couto, J.S.; Teodoro, A.J. Anticancer properties of Psidium guajava - a mini-review. Asian Pacific Journal of Cancer Prevention 2016, 17, 4199-4204.

16. Hirudkar, J.R.; Parma, K.M.; Prasad, R.S.; Sinha, S.K.; Lomte, A.D.; Itankar, P.R.; Prasad, S.K. The antidiarrhoeal evaluation of Psidium guajava L. against enteropathogenic Escherichia coli induced infectious diarrhoea. Journal of Ethnopharmacology 2020, 251, 112561. http://doi.org/10.1016/j.jep.2020.112561.

17. Jang, M.H.; Piao, X.L.; Kim, J.M.; Kwon, S.W.; Park, J.H. Inhibition of cholinesterase and amyloid-ßaggregation by resveratrol oligomers from Vitis amurensis. Phytotherapy Research 2008, 22, 544-549.

18. Shruthi, D.S.; Roshan, A.; Timilsina, S.S.; Sunita, S. A review on the medicinal plant Psidium Guajava Linn. (Myrtaceae). Journal of Drug Delivery \& Therapeutics 2013, 2013, 162-168, https://doi.org/10.22270/jddt.v3i2.404.

19. Simão, A.A.; Marques, T.R.; Marcussi, S.; Corrêa, A.D. Aqueous extract of psidium guajava leaves: Phenolic compounds and inhibitory potential on digestive enzymes. Anais da Academia Brasileira de Ciencias 2017, 89, 2155-2165. http://doi.org/10.1590/0001-3765201720160067.

20. Wang, L.; Wei, W.; Tian, X.; Shi, K.; Wu, Z. Improving bioactivities of polyphenol extracts from Psidium guajava L. leaves through co-fermentation of Monascus anka GIM 3.592 and Saccharomyces cerevisiae GIM 2.139. Industrial Crops and Products 2016, 94, 206-215,http://doi.org/10.1016/j.indcrop.2016.08.043.

21. Chang, C.H.; Hsieh, C.L.; Wang, H.E.; Peng, C.C.; Chyau, C.C.; Peng, R.Y. Unique bioactive polyphenolic profile of guava (Psidium guajava) budding leaf tea is related to plant biochemistry of budding leaves in early dawn. Journal of the Science of Food and Agriculture 2013, 93, 944-954.

22. Mercadante, A.Z.; Steck, A.; Pfander, H. Carotenoids from guava (Psidium guajava L.): Isolation and structure elucidation Journal of Agricultural and Food Chemistry 1999, 47, 145-151, http://doi.org/10.1021/jf980405r.

23. Ngbolua, K.; Lufuluabo, L.G.; Moke, L.E.; Bongo, G.N.; Liyongo, C.I.; Ashande, C.M.; Sapo, B.S.; Zoawe, B.G.; Mpiana P.T. A review on the Phytochemistry and Pharmacology of Psidium guajava L. (Myrtaceae) and Future direction. Discovery Phytomedicine 2018, 5, 7-13, http://doi.org/10.15562/phytomedicine.2018.58.

24. Zhu, M.; Phillipson, J.D.; Greengrass, P.M.; Bowery, N.E.; Ya, C. Plant polyphenols: Biologically active compounds or non-selective binders to protein?. Phytochemistry 1997, 44, 441-447, http://doi.org/10.1016/S0031-9422(96)00598-5.

25. Park, B.J.; Matsuta, T.; Kanazawa, T.; Park, C.H.; Chang, K.J.; Onjo, M. Phenolic compounds from the leaves of Psidium guajava II. quercetin and its glycosides. Chemistry of Natural Compounds 2012, 48, 477479, http://doi.org/10.1007/s10600-012-0280-7.

26. Arima, H.; Danno, G.I. Isolation of antimicrobial compounds from guava (psidium guajava 1.) and their structural elucidation. Bioscience, Biotechnology and Biochemistry 2002, 66, 1727-1730, http://doi.org/10.1271/bbb.66.1727. 
27. Begum, S.; Hassan, S.I.; Ali, S.N.; Siddiqui, B.S. Chemical constituents from the leaves of Psidium guajava. Natural Product Research 2004, 18, 135-140, http://doi.org/10.1080/14786410310001608019.

28. Raj, A.; Menon, V.; Sharma, N. Phytochemical screening, antimicrobial, antioxidant and cytotoxic potential of different extracts of Psidium guajava leaves. Vegetos 2020, 33, 750-758, http://doi.org/10.1007/s42535020-00151-4.

29. Azizan, N.A.; Zarina, N.; Wahab, A.; Mohamad, N.A.; Sham, A.; Othman, A.S. Antimicrobial Activity of Psidium Guajava Leaves Extract Against Foodborne Pathogens. International Journal of Psychosocial Rehabilitation 2020, 24, 318-326.

30. Dayam, O.; Pant, P.; Prakash, S.; Bansal, A. In vitro antimicrobial activity of hydroalcoholic extract of Psidium guajava L. International Journal of Medical Sciences 2018, 3.

31. Yeshiwas, D.; Mekonnen, A. Comparative study of the antioxidant and antibacterial activities of two guava (Psidium guajava) fruit varieties cultivated in Andasa Horticulture Site, Ethiopia. Chemistry Journal 2019, 4, 154-162, http://doi.org/10.31221/osf.io/wxpj9.

32. Rohmani, S.; Sebayang, J.P.B. Formulation and Antibacterial Activity Test on Ethanol Extract Gel of Guava Leaf ( Psidium guajava L.). International Journal of Innovative Science and Research Technology 2019, 4, 400-403.

33. Sharma, N.; Jana, A.M.; Pathak, N.; Singh, C.; Singh, P. A preliminary study on the antibacterial effects of ethanolic extract of Psidium guajava leaves on Bacteria isolated from urinary tract infection with special reference to Escherichia coli and Staphylococcus aureus. International Journal of Biotechnology and Biochemistry 2017, 13, 973-2691.

34. Susilawati; Amalia, E.; Oktariana, D.; Khairunnisa, M.S. Antibacterial Activity of Endophytic Fungi Isolated from the Leaves of Jambu Biji (Psidium guajava L.). Journal of Physics: Conference Series 2018, 1095, 0-7, http://doi.org/10.1088/1742-6596/1095/1/012041.

35. Rasool, M.; Malik, A.; Arooj, M.; Alam, M.Z.; Alam, Q.; Awan, M.; Asif, M.; Qazi, M.H.; Zaheer, A.; Khan, S.U.; Haque A.; Pushparaj, P.N.; Choudhry, H.; Jamal, M.S. Evaluation of antimicrobial activity of ethanolic extracts of azadirachta indica and psidium guajava against clinically important bacteria at varying ph and temperature. Biomedical Research (India) 2017, 28, 134-139.

36. Emmanuel, A.; Kubmarawa, D.; Sara, G.Y.; Wahu, A. Phytochemical Screening, Antioxidant and Antimicrobial Activities of the Essential Oils and Ethanol Extract of Psidium guajava Leaf. Asian Journal of Physical and Chemical Sciences 2019, 7, 1-8, http://doi.org/10.9734/ajopacs/2019/v7i430102.

37. Rajan, S.T.; Malathi, N.; Chamundeeswari, D.; Rose, C. Anti-microbial activity of Psidium Guajava leaf extract. Indian Journal of Public Health Research and Development 2019, 10, 257-262.

38. Dhiman, A.; Nanda, A.; Ahmad, S.; Narasimhan, B. In vitro antimicrobial activity of methanolic leaf extract of Psidium guajava L. Journal of Pharmacy and Bioallied Sciences 2011, 3, 226-229, http://doi.org/10.4103/0975-7406.80776. 